\title{
Fostering Critical Thinking through Socrates' Questioning in Iranian Language Institutes
}

\author{
Mansoor Fahim \\ Islamic Azad University, Science and Research Branch, Tehran, Iran \\ Email: dr.mfahim@yahoo.com \\ Mohammad B. Bagheri \\ Islamic Azad University, Science and Research Branch, Tehran, Iran \\ Email: mb.bagheri2010@yahoo.com
}

\begin{abstract}
Critical thinking is a western concept and as its history points out developed and flourished in the western world because the conditions were favorable. Developing critical thinking in non-western societies cannot be pursued unless the local exigencies are carefully considered. Fostering critical thinking in Iran as an Islamic country has its own obstacles and problems. Considering such limitations, this paper tries to offer practical ideas and viable strategies for developing and actualizing critical thinking through Socratic Questioning in Iranian language institutes based on Bloom's Revised Taxonomy and Paul's Taxonomy of questions. The main premise is: Questions are not merely meant to ask, but they have teaching potentiality. Through some class activities such as free discussions, active reading, analytical writing, and dynamic assessment, the teachers can cultivate critical thinking ability in the students. As the title of the article depicts, the interrelationship of three main themes is to be investigated: (1) critical thinking, (2) Socratic Questioning, and (3) Iranian language institutes. First, each of these three themes is treated respectively and then the mechanics of developing this skill in language institutes in Iran would be discussed.
\end{abstract}

Index Terms - analytical writing, Bloom's revised taxonomy, critical thinking, dynamic assessment, Paul's taxonomy of questions, Socratic questioning

\section{INTRODUCTION}

Dewey (1910) and Edward de Bono (1976), among so many educationalists, declared the aim of education is to teach young people to think. Critical thinking is a way to take charge of our thinking. Although critical thinking has a long history in the Western world, it is almost a new concept in most Eastern societies including Iran. There are few teachers and students who, when asked what they know about critical thinking or Socratic Questioning, have a vivid picture of these themes. This paper intends to discuss, as its title suggests, the issue of fostering critical thinking by using the potentiality of Socratic Dialectic in an Iranian context, namely language institutes. The interrelationships of three main themes are, therefore, to be investigated in this paper: (1) Critical Thinking, (2) Socratic Method, and (3) Iranian Language Institutes. Initially it would be logical to discuss these three themes respectively, and then delve into the mechanics of fostering critical thinking in Language institutes and recommend some techniques and strategies to enable the teacher and the students to implement critical thinking in Iranian language classrooms.

\section{CRITICAL THINKING}

Critical thinking has been defined and interpreted differently by different scholars and thinkers. Like many other concepts and constructs, there is no consensus on its definition. Richard Paul (1988) construes critical thinking as the ability to reach sound conclusions based on observation and information. Beyer (1983) describes critical thinking as assessing the authenticity, accuracy, and worth of knowledge, claims, beliefs, or arguments. Stephan Norris (1985) maintains that it helps students apply what they already know to evaluate their own thinking. Some scholars such as Paul (1987) believe constructs such as critical thinking should not be subjected to a one-line definition as such a definition would be limiting. In order to escape the limitations of a single definition it would be more desirable to create a framework which consists of different perspectives including alternative definitions. Wright (2002) on the other hand, emphasizes the importance of having a well thought out definition of critical thinking and maintains that when we define critical thinking we try to be clear about what we want to do; however, our working definition should include the core meaning of the original concepts and what most people mean by the term. This paper has no intention to stick to a single definition of critical thinking. Instead, the idea of critical thinking as a complex concept would be investigated by considering a variety of dimensions. Nonetheless, as the main focus of the paper is to introduce tactics and strategies to be used in Iranian language institutes to promote critical thinking through Socratic Questioning, those aspects of critical thinking which can be fostered through Socratic Method would be emphasized more. In order to make 
the discussion more concrete, it would be better to think of the main features of a critical thinker to present a holistic view of this general term. Critical thinkers:

- systematically monitor their thoughts,

- do not simply memorize a body of knowledge and use the basic tools of disciplined reasoning into every subject they study,

- ask deep and thought-provoking questions,

- examine different propositions which are offered for acceptance to find out whether they correspond to reality or not,

- gather pertinent information with great care and precision,

- try to understand the new information well enough to apply it to new situations,

- are not easily manipulated,

- use the strategies of active learning,

- try to develop higher order thinking,

- recognize unstated assumptions and values,

- apply their knowledge to new situations,

- comprehend and use language with clarity and accuracy,

- make connections among diverse pieces of information,

- challenge unexamined assumptions, beliefs, and values,

- do not render a judgment before considering all the facts and the relevant data,

- do not merely memorize discrete pieces of information,

- can distinguish those beliefs that are reasonable and logical from those which lack adequate evidence or rational foundation,

However, one should be careful not to misjudge people regarding being a critical thinker or not. Having explicit knowledge of what critical thinking is should not be the only criterion to call a person a critical thinker. Obviously there are people who apply some strategies of critical thinking, but may not be able to discuss explicitly what is meant by critical thinking. On the other hand, there are people who know what critical thinking is in theory, but do not implement it in practice. For the latter group, it is necessary to make critical thinking intuitive. They are like people who know the meaning of Democracy, but do not behave democratically in their daily lives.

\section{A short history of Critical Thinking}

Evidently the Greek philosopher Socrates set the agenda for critical thinking. He believed no idea can be taught directly, and tried to educate his students through questioning. He helped his students reach a deep level of understanding and thinking through questioning the underlying beliefs and assumptions. Socratic method of instruction required the students to consider different perspectives. The importance of this method was its capability in stimulating the students' thinking. Socrates pointed out how educative good and deep questions can be, and how such questions can lead to deeper thought. His method of questioning is known as "Socratic Questioning" and is the best known critical thinking teaching strategy. In the Renaissance $\left(15^{\text {th }}\right.$ and $16^{\text {th }}$ centuries) a flood of scholars began to think critically about religion, art, society, human nature, law, and freedom. Francis Bacon in "The Advancement of Learning" concentrated on the way people misused their minds and maintained that mind should not be left with its own tendencies. He laid the foundations for the scientific approach and modern science. Another text in critical thinking (Rules for the direction of the mind) was written by Descartes about fifty years later. He argued for the importance of disciplined mind and wellbased thinking. Descartes developed a method of critical thought based on the principles of systematic doubt. He believed every part of thinking should be questioned, doubted, and tested. Thomas Moore introduced a model called Utopia in which every domain of the world was subject to critique. Machiavelli laid the foundations for critical political thought. Hobbes and Locke tried to investigate human critical mind to open up new vistas of learning.

\section{Is Critical Thinking teachable?}

According to Walsh and Paul (1988) critical thinking is not the same as intelligence and does not necessarily develop with maturity. It must be taught to be improved. Peters (1967, cited in Garrison, 1991) argues that there is no innate tendency to think critically, neither is it easy to acquire it. On the whole there are two approaches to the idea of teaching critical thinking, the process approach and the content approach. Process approach is in favor of dealing with critical thinking as a separate and independent course while content approach votes for teaching it within established courses. Those who support the process view (e.g., Lipman, 1988) believe critical thinking is an enabling discipline and deserve separate instruction. Advocates of the content approach, on the other hand, maintain that teaching such cognitive skills is more effective provided the instruction is given in context (Ashton 1988). Some scholars such as Presseisen (1988) support a unified view and think critical thinking can be taught more effectively if the two approaches are combined.

\section{SOCRATIC METHOD}

Socrates has been recognized as one of the founders of western philosophy. He innovated a method of instruction based on questioning. Socratic questioning was based on a series of organized and systematic questions which helped the students gain awareness towards their ignorance, misconceptions, wrong assumptions, and false conclusions. This 
model of instruction does not rely on memorizing the discrete pieces of information a teacher lectures or a textbook presents. In this model questions are asked for which there are no definitive answers, in fact the questioner does not seek such answers. The philosophy behind this method is to stimulate the thinking. According to Sigel (1979) Socratic enquiry serves the cause of cognitive development because they activate representational thought. Socratic dialectic is neither a meandering chat nor recitation-style teaching in which the teacher asks a question, the student gives an answer and the teacher finally offers a feedback through his or her final remark. Socrates believed the true vocation of a teacher is to help the learners to collect their thoughts and build new understanding from previous knowledge. Through questioning, sometimes, we notice people cannot rationally justify their beliefs. Socratic dialectic is an effective tool to help people distinguish reasonable and logical beliefs from irrational and unfounded beliefs. Through questioning the students can be led to new discoveries, so the function of questions is not limited to assessing the amount of knowledge obtained but creating new levels of understanding, to uncover contradictions. In Socratic Method teachers are expected to abandon their role as deliverer of the course content and engage the students with the material

Gunter, Estes, and Mintz (2010) argue that the success of a classroom discussion depends on the kinds of questions that teachers prepare. They assert that "good questions are educative - they provide the opportunity for deeper thought" (p.192). Based on Bloom's Revised Taxonomy and Paul's Taxonomy of Socratic Questions, Gunter et al try to introduce different types of questions teachers can ask in order to not only evaluate and assess students' knowledge but also raise their level of understanding. Bloom's Taxonomy contains six types of questioning for six cognitive levels:

1. Remembering questions which ask students to recall what they have learned,

2. Understanding questions which ask students to explain what they have learned,

3. Applying questions which ask students to use new learning in other familiar situations,

4. Analyzing questions which ask students to break what they have learned into its parts and explore the relationships among them,

5. Evaluative questions which ask students to render a judgment,

6. Creating questions which ask students to generate new ways of thinking about issues and subjects,

Paul's Taxonomy categorizes Socratic questions into six types as:

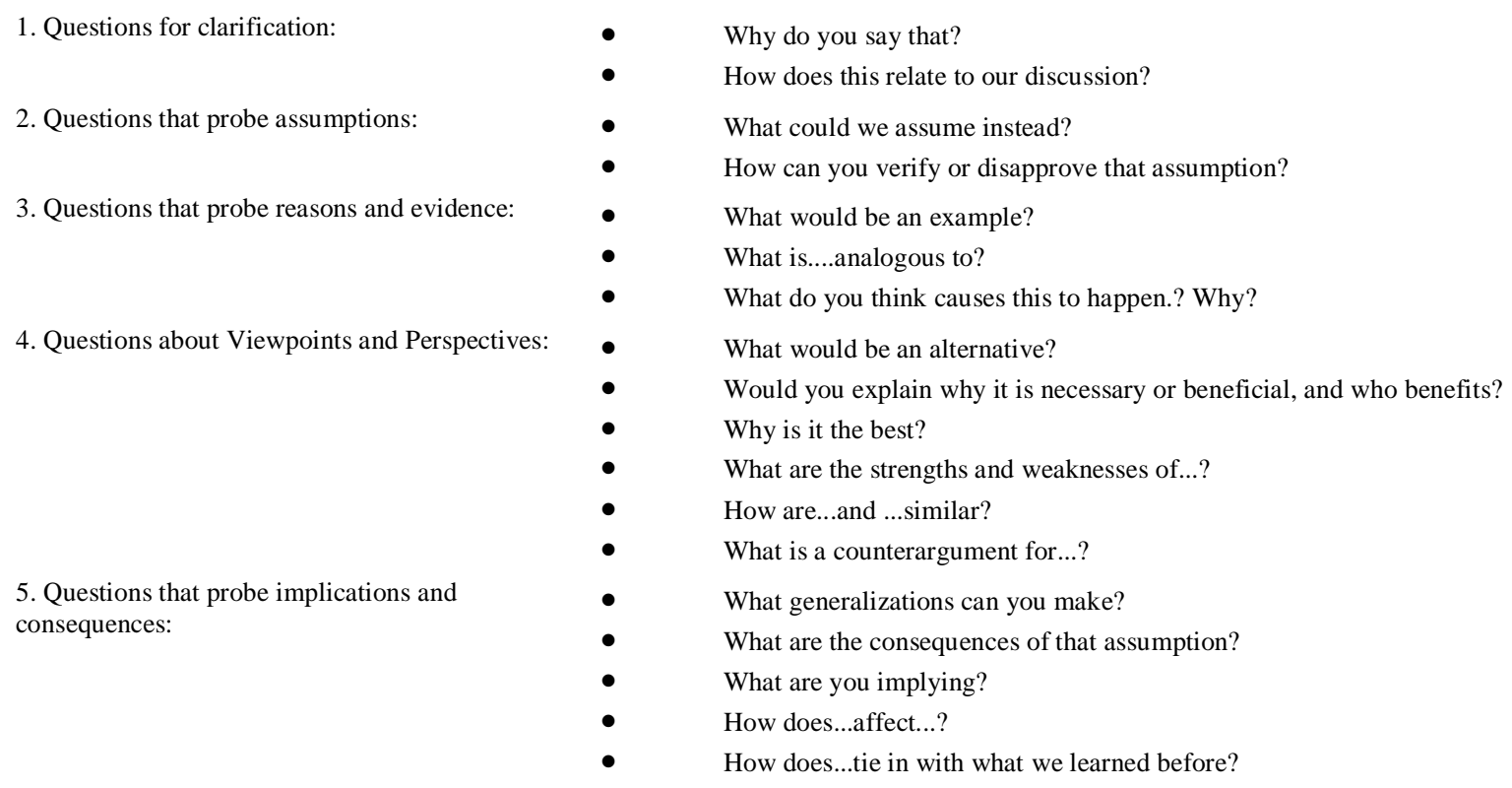

\section{IRANIAN LANGUAGE INSTITUTES}

In Iran Ministry of Education accredits, supervises, and monitors language institutes. Though different types of language courses for the instruction of different languages are offered, the main language being instructed is English and students from different age groups attend English language courses. The majority of these students take English conversation courses, though, there are students whose aim is to pass IELTS or TOEFL tests, need to improve their English to be ready for school and university entrance exams, or need to improve their English for job purposes. Each year a flood of enthusiasts with a variety of motives attend different courses in order to enhance their English (or any other foreign language).

Iran is an Islamic country and the majority of people are Muslims who respect and follow the instructions of the Holy Quran. Although several times in this holy book it is mentioned that there are "signs for people who think deeply" (Quran: Chap. 16, verse 69; Chap.39, verse 42; Chap. 45, 13) and Quran encourages people to listen to different sayings and follow the best (" Give good tidings to My servants who listen to speech and follow the best of it, those are the ones 
Allah has guided and those are people of understanding". Chap. 39 verse 18) people who are proud of their religion are rarely optimistic towards Western values. In spite of the fact that the above-mentioned verses, quoted from Quran, are obviously an invitation to be a critical thinker, questioning the beliefs and values is considered an unforgivable sin and the person who commits this, would be accused of impugning the values and infusing doubts. Following the Islamic revolution in 1979, Iran adopted an Islamic version of government which is so strict with what is considered to be Islamic laws. It is advisable to approach the issue of critical thinking with great care and understanding. It is never possible to question the beliefs and values in the name of fostering critical thinking. So a teacher who decides to develop critical thinking among the students can discuss issues which do not question the religious or political matters. If the point is to teach the fundamentals of critical thinking, then there are other less threatening topics which are less hazardous. The students should learn to develop a habit of not accepting everything unless there are enough evidence, learn to familiarize themselves with conflicting views, learn not to base their actions on personal feelings, learn to ask deep questions, and learn to live with uncertainty. They should learn that knowledge is always subject to change and the truth is not necessarily contained in the textbook. They should learn that merely memorizing the facts is a trivial pursuit and knowing facts requires thought. The point is to familiarize the students with the merits of critical thinking. Once they make a habit of being a critical thinker they will ask deep questions about everything. Besides the teacher should be cautious not to create tensions in the classroom. As Senior (2006) warns us "clashes between value systems, even between students from the same cultural background can sometimes come to the fore in language classroom".

Another issue which is worth considering is the fact that Iranian students are not familiar with the concept of critical thinking the way it was prominently developed in the 1980s, which, according to Feuerstein (1999), asserts schools should be less concerned with imparting information and requiring the memorization of empirical data. The educational system, in Iran, is more or less traditional. In this didactic system teachers provide explanations on the content of the course books and students are expected to memorize the materials and finally those who can recall more information get better grades. A simple interview with students and teachers depicts this truth. As a matter of fact there is no specific course in any level to familiarize students with critical thinking. Based on the interviews I had with language teachers and learners in different language institutes I noticed both groups were unaware of the role of questions to teach and they thought of questions as evaluative tools rather than a means to instruct. The type of the questions being used were mostly questions which target the memorized information.

\section{Actualization of Critical Thinking}

Learning a second language by itself means learning to think and feel in another way because new horizons will be in front of the learners and they are no longer confined to think and feel within the limitations of the first language (Brown, 2007). One can conclude that learning a second language, per se, is a step forward to be a critical thinker as the learner gets access to new ways of thinking and seeing the world. In this way, courses to teach second or foreign languages are great opportunities for learners to enhance critical thinking skills. If critical thinking means looking at the world from different perspectives, so learning a foreign language provides the learners with this capability.

However, this is not the whole story. One cannot easily conclude that learning English will necessarily instill, for example, democratic values. As Karmani (2005) argues those who implemented 9/11 attacks were so proficient in English, and their attack would have been inconceivable if they had not known English. They used not only American planes to hit their targets, but also American English.

Considering the limitations of fostering critical thinking in Iran, the teacher has to embark on this duty with great care and full attention. Being familiar with different types of activities which promote critical thinking in L2 classrooms, the teachers provide the opportunity for the learners to develop their thinking and learning. There are some techniques and class activities which the teacher can resort to, in order to actualize critical thinking in the L2 learners.

Active Reading: Students should be encouraged to interact with the reading material instead of reading passively. Of course there are students who underline or highlight the text they are reading, but that is not enough. Active learners comment on what they read, raise questions, and think about what they read. Students should learn not only the information about what they read, but also learn to think about the subject. Being familiar with Socratic Questioning causes the students to raise deep questions about the materials they read. The students are no longer passive receptors into which teachers deposit concepts and information. The teacher should first raise the L2 learners' awareness toward various kinds of questions, based on Paul's Taxonomy, and then ask students to read a text and write questions. Asking comprehension questions which transcend memorization and encourage the learners to think profoundly, is one way to actualize critical thinking in the classroom.

Free Discussions: According to Dillon (1994) discussion is a particular form of group interaction where members join together in order to address a question of common concern. Ur (1981) argues that although the main aim of a discussion in a foreign language course may be efficient fluency practice, it can help the students to participate constructively and cooperatively in a discussion. This involves logical thought and debating skills as well. When students share their views with their teacher, it is the best time to identify the misconceptions and through Socratic Questioning raise their awareness. During the course of discussion the teacher has the opportunity to emphasize the need for all data used in reasoning to be reinterpreted, how inferences are made and the way wrong assumptions which people take them for granted can deceive them. Also, teachers should empower the students to distinguish facts from 
opinions, raw data from interpretations of the data. Sensitizing the students to the inferences they make and to assumptions that underlie their thinking enables them to gain command over their thinking. Students learn to weigh evidence and analyze ideas even if they run contrary to deeply held views. Students are provided with the chance to develop metacognitive skills as they receive feedback on their thoughts and the thoughts of their peers.

Analytic Writing: Analytical writing tests critical thinking and analytical writing. It assesses learners' ability to articulate and support complex ideas, construct and evaluate arguments, and sustain a focused and coherent discussion. It does not assess specific content knowledge. A teacher who is committed to teach critical thinking to students asks them to go beyond Descriptive writing in which ideas are repeated towards Analytic writing where ideas are explained, critiqued, evaluated, and applied. Having Socratic method of questioning in mind will foster this type of writing.

Dynamic Assessment: According to Rod Ellis (2008) dynamic assessment refers to a mode of assessment in which the learner's performance is modified during assessment itself. This type of assessment is in line with Socratic Method in which questions led the student to the answer. In addition to this type of assessment, teachers who are familiar with Paul and Bloom's taxonomies of questions are expected to evaluate their students and assess their ability, knowledge and or understanding not only through questions which merely target memorized materials, but also through evaluative, analyzing, applying, creating, and understanding questions as well. Familiarity with Socratic method and the spectrum of questions leads us to this objective.

\section{CONCLUSION}

In this article, the main obstacles for developing and actualizing critical thinking skills in an Iranian context was discussed. It was pointed out that the educational system in Iran is in dire need of becoming familiarized with Socratic Method of questioning to improve and detach from the current memorization based instruction and learning. Paul's taxonomy of questions and Bloom's taxonomy of questions were introduced as two models for categorizing questions. Iranian language institutes were chosen for implementing the classroom techniques and activities. Four specific classroom activities namely Free discussions, Active Reading, Analytical writing, and Dynamic Assessment were introduced as having the potentiality to foster critical thinking in Iranian EFL learners.

\section{REFERENCES}

[1] Ashton, P. (1988). Teaching higher-order thinking and content: An essential ingredient in teacher preparation. Gainesville, FL: University of Florida.

[2] Beyer, B. (1983). Common sense about teaching thinking skills. Educational leadership, 41, 44-49. EJ 289-719.

[3] Brown, H. G. (2007). Principles of language learning and teaching, $\left(5^{\text {th }}\right.$ ed.).New York: Pearson Longman.

[4] de Bono, E. (1976). Teaching thinking. London: Maurice Temple Smith.

[5] Dewey, J. (1910). How we think. Boston, MA: Heath.

[6] Dillon, J. T. (1994). Using discussions in classrooms. Buckingham: Open University Press.

[7] Ellis, R. (2008). The study of second language acquisition ( $2^{\text {nd }}$ ed.). Oxford: Oxford University Press.

[8] Feuerstein, M. (1999). Media literacy in support of critical thinking. Journal of Educational Media, 24, 43-54.

[9] Garrison, D. R. (1991). Critical thinking and adult education: A conceptual model for developing critical thinking in adult learners. International Journal of Lifelong education, 10, 287-303.

[10] Gunter, M. A., Estes, T. H., \& Mintz, S. L. (2010). Instruction: A model approach, $\left(5^{\text {th }}\right.$ ed.). Boston: Pearson Education, Inc.

[11] Karmani, S. (2005). English, 'Terror', and Islam. Applied Linguistics, 26, 262-267.

[12] Lipman, M. (1988). Philosophy goes to school. Philadelphia: Temple University Press.

[13] Norris, S. P. (1985). Synthesis of research on critical thinking. Educational Leadership, 42, 40-45. EJ 319-814.

[14] Paul, R. (1988). Critical thinking in the classroom. Teaching $K-8,18,49-51$.

[15] Presseisen, B. (1988). Avoiding battle at curriculum gulch: Teaching thinking and content. Educational Leadership, 45, 7-8.

[16] Senior, R. M. (2006). The experience of language teaching. Cambridge: CUP.

[17] Sigel, I. E. (1979). On becoming a thinker: A psychoeducational model. Educational Psychologist, 14, 70-78.

[18] Ur, P. (1981). Discussions that work: task-centered fluency practice. Cambridge: CUP.

[19] Walsh, D., \& Paul, R. (1988). The goal of critical thinking: From educational ideal to educational reality. Washington, D.C.: American Federation of Teachers.

[20] Wright, I. (2002). Challenging students with the tools of critical thinking. The social studies, 93(6), 257-261.

Mansoor Fahim was born in Nahavand in 1946. He received a Ph.D. in TEFL from Islamic Azad University in Tehran, Iran in 1993. As for his professional background, he was a member of the faculty of English Language and Literature at Allameh Tabataba' $i$ University in Tehran, Iran from 1981 to 2008 when he was retired as an associate professor of TEFL. At present, Dr. Fahim runs Research methods, Psycholinguistics, Applied Linguistics, Second Language Acquisition, and Seminar classes at MA level, and First Language Acquisition, Psycholinguistics, and Discourse Analysis courses at PhD level at a number of universities including Allameh Tabataba'i and Islamic Azad Universities, Science and Research Campus, Tehran, Iran. He has also published several articles and books mostly in the field of TEFL and has translated some books into Farsi. 
Mohammad B. Bagheri was born in Rafsanjan in 1969. He is currently doing his PhD studies in TEFL at Islamic Azad University, Science and Research Campus, Tehran, Iran. He is a faculty member at Islamic Azad University, Karaj Branch, Iran. His main interests are SLA, language testing and assessment, and teaching oral skills. 